\section{Host Resistance to Pear Psylla of Breeding Program Selections and Cultivars}

\author{
Richard L. Bell ${ }^{1,2}$ \\ U.S. Department of Agriculture, Agricultural Research Service, Appalachian \\ Fruit Research Station, 2217 Wiltshire Road, Kearneysville, WV 25430-9425
}

Additional index words. Pyrus, antixenosis, Cacopsylla pyricola Förster, Hemiptera, Psyllidae, nymphal feeding, genetic resources

\begin{abstract}
Twenty-one pear cultivars and breeders' selections with interspecific pedigrees involving Pyrus ussuriensis Max. or P. pyrifolia (Burm.) Nakai crossed with $\boldsymbol{P}$. communis were assessed for resistance to pear psylla (Cacopsylla pyricola Förster) using a nymphal feeding antixenosis assay. The proportion of nymphs live and present on the plants varied from 0.52 for Purdue 77-73, a $P$. ussuriensis $\times P$. communis hybrid, to 0.08 for 'Zelinka', a $P$. communis cultivar from eastern Europe. Two $P$. ussuriensis $\times P$. communis hybrid selections (NY 10355 and NY 10359) and the $P$. communis landrace cultivars, Batjarka and Zelinka, were the most resistant to nymphal feeding. NJ B9 T1 T117 may also be a useful source of resistance. The most resistant germplasm should be valuable genetic resources for the breeding of new pear cultivars with resistance to pear psylla.
\end{abstract}

Pear psyllids are a serious insect pest of the cultivated European pear (Pyrus communis L.) in the production regions of North America and Europe. In North America, Cacopsylla pyricola (Förster) is the only psyllid pest of pears, whereas in Europe, C. pyri (L.) and C. pyrisuga (Förster) are also endemic. Cacopsylla bidens (Šlc) is endemic to parts of southern and eastern Europe as well as the Middle East. The insect has rapidly developed resistance to most of the pesticides used for control, and biological controls alone have rarely provided sufficient control for commercial production. The annual cost per hectare of chemical control is high. Cultivars with durable resistance would enhance the economic and environmental sustainability of pear production by reducing producer costs and pesticide use.

These species of pear psylla and their host apparently coevolved in Europe. Investigations of western European cultivars identified only a few moderately resistant cultivars,

Received for publication 19 Oct. 2011. Accepted for publication 17 Dec. 2012.

I thank Wayne Zook, Gabriel Wilmoth, and Natalie Carpenter for technical assistance and data collection. I also thank Dr. Robert C. Lamb of Cornell University, Dr. L. Fredric Hough of Rutgers University, Dr. Herb Barrett of the University of Illinois, and Dr. Jules Janick of Purdue University for providing their pear selections.

Mention of a trademark, proprietary product, or vendor does not constitute a guarantee or warranty of the product by the U.S. Department of Agriculture and does not imply its approval to the exclusion of other products or vendors that may also be suitable. USDA is an equal opportunity provider and employer.

${ }^{1}$ Research Horticulturist.

${ }^{2}$ To whom reprint requests should be addressed; e-mail richard.bell@ars.usda.gov. including 'Spina Carpi' (Quarta and Puggioni, 1985), 'Triomphe de Ronchin', 'Joséphine des Malines', 'Doyenne du Poitiers', and 'D'Août Lamer' (Robert et al., 2004, 2005). Higher levels of resistance have been identified in the small-fruited Asian pear species, P. betulifolia Bunge, $P$. calleryana Decne., $P$. fauriei Schneid., P. ussuriensis Maxim., and $P . \times$ bretschneideri Rehd. and in a few genotypes of the European "snow pear," P. nivalis Jacq. (Quamme, 1984; Westigard et al., 1970), and in $P$. ussuriensis $\times P$. communis hybrids (Harris, 1973; Harris and Lamb, 1973; Pasqualini et al., 2006; Quamme, 1984). Pomologists and breeders have also been collecting wild germplasm and landrace cultivars to identify diverse sources of resistance for use in the development of new psyllaresistant cultivars (van der Zwet et al., 1987, 1989).

The behavioral and physiological responses of arthropod pests to resistant host genotypes are termed modes of host plant resistance as distinct from the underlying mechanisms of resistance. Major modes of host plant resistance are 1) antixenosis, which can be observed in terms of disruptions to insect orientation and settling (i.e., host finding) and inhibition of feeding and oviposition; 2) antibiosis, observed as delayed development, increased mortality, and reduced fecundity and egg hatchability; and 3) tolerance or the ability to withstand infestation without damage (Painter, 1951). The term antixenosis was introduced by Kogan and Ortman (1978) to define the inhibitory effects of the host plant, whereas nonpreference refers to behavior exhibited by the pest. Feeding antixenosis has been established as a key mode of resistance, because reduced feeding frequency is associated with reduced oviposition as well as increased mortality and delayed development (Bell,
1991; Bell and Puterka, 2004; Butt et al., 1988, 1989; Puterka, 1997; Robert et al., 1999).

Observation of breeders' selections in the orchard suggested that some genotypes were at least moderately resistant to pear psylla (unpublished data). The purpose of this research was to assess the degree of resistance in breeders' selections in a controlled experiment. The overall goal was to select the most promising parents for further breeding and cultivar development.

\section{Materials and Methods}

Germplasm. Seven pear cultivars and 14 selections from the breeding programs of the U.S. Department of Agriculture, Cornell University, Rutgers University, University of Illinois, and Purdue University were used in this study. The cultivars and selections represented a diverse genetic background with pure Pyrus communis as well as interspecific hybrids with $P$. ussuriensis and $P$. pyrifolia. There were five $P$. communis cultivars and selections, six $P$. communis $\times P$. pyrifolia hybrids, and $10 P$. communis $\times P$. ussuriensis hybrids. The interspecific hybrids included both first generation as well as backcross hybrids. The exact parentage of Purdue 77-73, 'Luscious', and 'Summercrisp' is unknown but is thought to be $P$. communis $\times$ $P$. ussuriensis backcross hybrids.

Resistance assay. Five single-shoot plants of each genotype were generated by budding onto greenhouse-grown 'Bartlett' seedling rootstock grown in Metro Mix 510 potting soil containing a starter fertilizer (Scott's, Marysville, $\mathrm{OH})$ in standard 8 -in. $(20 \mathrm{~cm})$ plastic pots. The trees were also fertilized weekly with Peter's General Purpose 20-2020 fertilizer (Scott's). All plants were grown in a pesticide-free greenhouse until they each had at least $20 \mathrm{~cm}$ of shoot growth. All but the top four leaves were removed just before infestation, and a band of Tangle-Trap (The Tanglefoot Company, Grand Rapids, MI) was applied to the stem just basal to the fourth node to trap nymphs migrating off of the plant. No phytotoxicity on the stem resulting from the Tangle-Trap was evident when data were collected. The top two youngest, fully expanded leaves of each plant were each infested on the abaxial side with 10 second or third instar nymphs of pear psylla from a young laboratory colony for a total of 20 nymphs per plant. The transfer was accomplished by removing an infested leaf from a colony plant, placing it under a stereomicroscope, "teasing" a nymph with a singlehair brush until it appeared to have withdrawn its stylet and begun to move, lifting the nymph off of the leaf with the single hair, and then transferring the nymph to a leaf of the test plant. After infestation, the plants were maintained in a growth chamber at $25 \pm 1{ }^{\circ} \mathrm{C}$ and a photoperiod of $16 \mathrm{~h} / 8 \mathrm{~h}$ (light/dark) provided by a mixture of incandescent and highintensity fluorescent bulbs. The experiment was conducted as a randomized complete block design with five sets of genotypes as 
individual tree replicates. As a result of "bud misses," only three or four trees were available for six of the selections/cultivars. The numbers of live, actively feeding and dead nymphs were counted after $72 \mathrm{~h}$. Active feeding was indicated by the presence of excreted "honeydew" associated with the nymph. Missing nymphs as well as those that migrated off the four test leaves and down the plant stem were presumed to be reacting to the antixenotic property of the host genotype. Counts on individual leaves and stems were summed for a total per plant. The numbers of live, feeding, and dead nymphs were divided by the original 20 nymphs to compute the corresponding proportions.

Statistical analysis. Data for all experiments were analyzed to determine whether the residuals met the assumptions underlying the analysis. Homogeneity of variances was tested by an examination of residual plots. Normality was tested using the Shapiro-Wilk test in SAS PROC UNIVARIATE (SAS Institute Inc., 1990) and examination of box and normal probability plots. A histogram with a fitted normal curve was also used to visually assess deviation from normality. Correlation of mean and residuals was examined using a plot of residual vs. predicted values and tested by SAS PROC CORR option SPEARMAN. Type IV sums of squares were computed. All analyses were performed using SAS PROC MIXED (Littell et al., 1996). The linear model for the analyses of genotype differences for each response variable was a mixed effects models with replication as a random effect and genotype as a fixed effect. Least-squares means and SEs were computed. Mean separation for this procedure was performed using the Tukey-Kramer honestly significant difference method. The Tukey option was used to adjust for multiple comparisons. Mean separation letters for main effects were assigned by the SAS macro PDMIX 800 (Saxton, 1998).

Differences among broad species pedigree classes were also analyzed. Firstgeneration interspecific hybrids were grouped with interspecific backcross hybrids. In this case, species was the fixed effect, and genotype within species and replication were random effects. Assumptions were tested as described previously. The rank correlation between proportion of live nymphs and proportion of feeding nymphs was computed using SAS PROC CORR with the SPEARMAN option.

The preliminary analysis of proportion feeding and proportion alive to test whether the data met the assumptions detected four outliers in the feeding data (single replicates for NJ A2 R59 T69, NJ Rock R25 T238, 'Golden Spice', and US65064-044), and these data were deleted from further analysis. The analysis was rerun, and it did not detect significant deviations from normality, but the residual plots showed some variation in variances and a tendency for a positive relationship between means and variances. However, the coefficients for the correlation between means and residuals were not statistically significant for proportion alive and proportion feeding but significant for proportion dead. Arcsin square root transformation, with Bartlett's correction for 0 and $100 \%$, was performed (Steel and Torrie, 1960), but the transformation did not improve the inequality of variances, and therefore, the raw data analysis is presented. Similar results were obtained when checking the species analysis for meeting the assumptions. Again, the raw data analysis is presented.

\section{Results and Discussion}

Statistically significant differences among genotypes in the proportion of live nymphs $(\operatorname{Pr}>\mathrm{F}=0.0001 ; \mathrm{df}=20,66)$ and proportion of feeding nymphs ( $\mathrm{Pr}>\mathrm{F}<0.0001 ; \mathrm{df}=20$, $66)$ were detected by the analysis of variance. Differences among genotypes for proportion dead were non-significant $(\operatorname{Pr}>\mathrm{F}=0.2632$; $\mathrm{df}=20,66)$, ranging from 0.01 for NJ Rock R27 T65 to 0.013 for IND TH 15-133. Differences resulting from replication were significant for proportion live $(\mathrm{Pr}>\mathrm{F}=$ $0.0009 ; \mathrm{df}=4,66)$ and proportion dead $(\operatorname{Pr}>$ $\mathrm{F}=0.0172 ; \mathrm{df}=4,66$ ) but not significant for proportion feeding $(\operatorname{Pr}>\mathrm{F}=0.0988 ; \mathrm{df}=4,66)$. The proportion of live varied from a high of 0.61 for US $66167-009$ to a low of 0.08 for
'Zelinka' (Table 1). The proportion of nymphs feeding varied from 0.52 for Purdue 77-73 to 0.04 for 'Zelinka'. There was considerable overlap of significant groups for both live and feeding nymphs. The usual explanation is a high degree of variability among replicate plants. Another feature of these data was that the highest proportions of live and feeding nymphs were much lower than that observed in previous experiments (Bell, 1992, 2003; Bell and Stuart, 1990). For example, in our previous experiments, the percentage of nymphs alive on 'Bartlett' after 24 or $48 \mathrm{~h}$ ranged from $76 \%$ to $89 \%$, whereas the percentage feeding was as low as $43 \%$ to $61 \%$ but was also $75 \%$ to $86 \%$. The cause of these differences is undetermined. The method of transferring nymphs was assumed to reduce the likelihood of injury to the nymphs, but even on 'Bartlett', $57 \%$ of the nymphs were either missing or trapped in the Tangle-Trap. Past studies also used five single-tree replicates with 20 nymphs per tree and were able to more clearly separate classes of resistance, although also with some overlap. Shoot growth was active with expanding leaves for all trees. The rank correlation between the proportions of live and feeding nymphs was highly significant $(r=0.84 ; \operatorname{Pr}>r<0.0001$, $\mathrm{df}=40)$.

Table 1. Nymphal feeding antixenosis of genetically diverse pear cultivars and breeding selections.

\begin{tabular}{|c|c|c|c|c|}
\hline Genotype & Species pedigree $^{z}$ & No. of trees & Proportion live & Proportion feeding \\
\hline Purdue 77-73 & com $\times$ uss $\mathrm{BC}$ ? & 3 & $0.52 \pm 0.09 \mathrm{a}^{\mathrm{y}}$ & $0.52 \pm 0.08 \mathrm{a}$ \\
\hline NJ 11 & com $\times$ pyr $\mathrm{BC}_{1}$ & 4 & $0.53 \pm 0.08 \mathrm{a}$ & $0.42 \pm 0.07 \mathrm{ab}$ \\
\hline US 66167-009 & com $\times$ pyr selfed & 4 & $0.61 \pm 0.08 \mathrm{a}$ & $0.41 \pm 0.07 \mathrm{ab}$ \\
\hline Bartlett & $\mathrm{com}$ & 5 & $0.43 \pm 0.07 \mathrm{ab}$ & $0.39 \pm 0.06 \mathrm{ab}$ \\
\hline IND TH 15-133 & com $\times$ pyr $\mathrm{BC}_{1}$ & 5 & $0.55 \pm 0.07 \mathrm{a}$ & $0.39 \pm 0.06 \mathrm{ab}$ \\
\hline $\begin{array}{l}\text { Obican Vodenac } \\
\text { Abc }\end{array}$ & $\mathrm{com}$ & 5 & $0.45 \pm 0.07 \mathrm{ab}$ & $0.37 \pm 0.06$ \\
\hline $\begin{array}{l}\text { ILL 5E-18 } \\
\text { Abcd }\end{array}$ & com $\times p y r$ & 4 & $0.54 \pm 0.08 \mathrm{a}$ & $0.36 \pm 0.07$ \\
\hline $\begin{array}{l}\text { Golden Spice } \\
\text { Abcd }\end{array}$ & com $\times$ uss & 3 & $0.47 \pm 0.09 \mathrm{ab}$ & $0.34 \pm 0.08$ \\
\hline $\begin{array}{l}\text { Luscious } \\
\text { Abcd }\end{array}$ & com $\times$ uss $\mathrm{BC}^{\mathrm{w}}$ & 5 & $0.44 \pm 0.07 \mathrm{ab}$ & $0.34 \pm 0.06$ \\
\hline $\begin{array}{l}\text { OHUS 66170-022 } \\
\text { Abcd }\end{array}$ & com $\times$ pyr $\mathrm{BC}_{1}$ & 5 & $0.52 \pm 0.07 \mathrm{a}$ & $0.33 \pm 0.06$ \\
\hline $\begin{array}{l}\text { Summercrisp } \\
\text { Abcd }\end{array}$ & com $\times$ uss $\mathrm{BC}^{\mathrm{w}}$ & 5 & $0.41 \pm 0.07 \mathrm{ab}$ & $0.29 \pm 0.06$ \\
\hline $\begin{array}{l}\text { NJ A2 R21 T89 } \\
\text { Abcd }\end{array}$ & com $\times$ uss $\mathrm{BC}_{1}$ & 5 & $0.38 \pm 0.07 \mathrm{ab}$ & $0.29 \pm 0.06$ \\
\hline $\begin{array}{l}\text { NJ Rock R27 T65 } \\
\text { Abcd }\end{array}$ & com $\times$ pyr $\mathrm{BC}_{1}$ & 5 & $0.44 \pm 0.07 \mathrm{ab}$ & $0.28 \pm 0.06$ \\
\hline $\begin{array}{l}\text { NJ A2 R59 T69 } \\
\text { Abcd }\end{array}$ & com $\times$ uss $\mathrm{BC}_{1}$ & 4 & $0.35 \pm 0.08 \mathrm{ab}$ & $0.25 \pm 0.07$ \\
\hline $\begin{array}{l}\text { NJ Rock R25 T238 } \\
\text { Abcd }\end{array}$ & com $\times$ uss $\mathrm{BC}_{1}$ & 4 & $0.35 \pm 0.08 \mathrm{ab}$ & $0.23 \pm 0.07$ \\
\hline $\begin{array}{l}\text { NJ B9 R1 T117 } \\
\text { Abcd }\end{array}$ & com $\times$ uss $\mathrm{BC}_{1}$ & 4 & $0.26 \pm 0.08 \mathrm{ab}$ & $0.16 \pm 0.07$ \\
\hline $\begin{array}{l}\text { US 65064-044 } \\
\text { Abcd }\end{array}$ & com & 3 & $0.40 \pm 0.09 \mathrm{ab}$ & $0.14 \pm 0.08$ \\
\hline NY 10355 & com $\times$ uss $\mathrm{BC}_{1}$ & 5 & $0.36 \pm 0.07 \mathrm{ab}$ & $0.10 \pm 0.06 \mathrm{bcd}$ \\
\hline NY 10359 & com $\times$ uss $\mathrm{BC}_{1}$ & 3 & $0.26 \pm 0.09 \mathrm{ab}$ & $0.07 \pm 0.08 \mathrm{bcd}$ \\
\hline Batjarka & $\mathrm{com}$ & 5 & $0.10 \pm 0.07 \mathrm{~b}$ & $0.05 \pm 0.06 \mathrm{~cd}$ \\
\hline Zelinka & $\mathrm{com}$ & 5 & $0.08 \pm 0.07 \mathrm{~b}$ & $0.04 \pm 0.06 \mathrm{~d}$ \\
\hline
\end{tabular}

${ }^{\mathrm{z}}$ Abbreviations for species: com $=P$. communis; pyr $=P$. pyrifolia ; uss $=P$. ussuriensis. $\mathrm{BC}_{1}$ denotes a first generation backcross to another $P$. communis parent.

${ }^{y}$ Means in the same column followed by the same letter are not statistically different as determined by the Tukey-Kramer honestly significant difference method $(P=0.05)$ using SAS PROC MIXED (Littell et al., 1996).

'The clone designated 'Obican Vodenac' in this study is probably not the same clone labeled 'Obican Vodenac' in the National Plant Germplasm System.

wPedigree is uncertain, so generation of backcross not given. 
Table 2. Nymphal survival and feeding according to species pedigree.

\begin{tabular}{lccc}
\hline & \multirow{2}{*}{$\begin{array}{c}\text { No. of } \\
\text { genotypes }\end{array}$} & Live & Mean proportion $( \pm \mathrm{SE})$ \\
\cline { 2 - 4 } Species group & $\mathrm{z}$ & $0.53 \pm 0.03 \mathrm{a}^{\mathrm{y}}$ & $0.36 \pm 0.03 \mathrm{a}$ \\
communis $\times$ pyrifolia & 6 & $0.38 \pm 0.03 \mathrm{~b}$ & $0.26 \pm 0.03 \mathrm{~b}$ \\
communis $\times$ ussuriensis & 10 & $0.29 \pm 0.03 \mathrm{~b}$ & $0.20 \pm 0.03 \mathrm{~b}$ \\
communis & 5 &
\end{tabular}

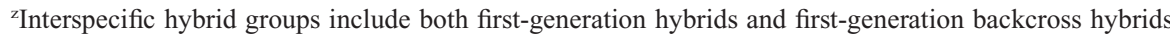
$\left(\mathrm{BC}_{1}\right)$

${ }^{\mathrm{y}}$ Means in the same column followed by the same letter are not statistically different as determined by the Tukey-Kramer honestly significant difference method $(P=0.05)$ using SAS PROC MIXED (Littell et al., 1996).

When the data grouped into species pedigree were analyzed, differences in live nymphs resulting from species were significant $(\mathrm{Pf}>\mathrm{F}<0.0001$, $\mathrm{df}=2,66)$ as were differences resulting from genotype within species $(\mathrm{Pr}>\mathrm{F}=0.0212 ; \mathrm{df}=18,66)$ and differences resulting from replication $(\mathrm{Pr}>$ $\mathrm{F}=0.0009 ; \mathrm{df}=4,66$ ) (Table 2). Differences in feeding among species were also significant $(\operatorname{Pr}>\mathrm{F}=0.004$; df $=2,66)$, and differences among genotypes within species were also significant $(\mathrm{Pr}>\mathrm{F}=0.0002$; $\mathrm{df}=$ 18, 66) (Table 2). Differences among replications were non-significant $(\operatorname{Pr}>\mathrm{F}=0.0988$; $\mathrm{df}=4,66)$. Differences in the proportion dead nymphs were significant only for the effect of replication $(\mathrm{Pr}>\mathrm{F}=0.0172 ; \mathrm{df}=4,66)$.

The $P$. communis group, largely as a result of the resistance of 'Batjarka' and 'Zelinka', was the most resistant and was not significantly different from the $P$. communis $\times$ $P$. ussuriensis backcross hybrid group. These two cultivars are putatively $P$. communis (van der Zwet et al., 1987) and are similar to 11 other psylla-resistant cultivars from eastern Europe in having large, thick leaves. The fruit are large and pyriform with a coarse, firm texture. Deciduous calyxes are sometimes observed, a trait they have in common with $P$. pyrifolia and a few genotypes of wild pear observed in Hungary. 'Batjarka' is a triploid (USDA, ARS, National Genetic Resources Program, 2012). The clone labeled 'Zelinka' at the Appalachian Fruit Research Station may be different from that at the National Clonal Germplasm Repository (NCGR) and is very similar in fruit and leaf phenotypes with 'Batjarka', 'Erabasma', 'Jeribasma', 'Kalman', Obican Vodenac' (NCGR clone), 'Topka', and 'Vodenac', all pear psylla-resistant clones that are triploids. Therefore, it is possible that my clone of 'Zelinka', obtained directly from the U.S. Plant Introduction Center at Glenn Dale, MD, may also be a triploid, but that needs to be verified. The occurrence of triploidy might lead to the speculation that these cultivars are not pure P. communis.

Ovipositional antixenosis, and antibiosis, observed as delayed development and increased mortality are also important modes of resistance. The combined effects of these modes will result in varying degrees of population development and damage in the orchard. Although correlated with these modes, nymphal feeding antixenosis is only one part of the resistance phenomenon.

The high degree of resistance of 'Batjarka' and 'Zelinka' previously observed (Bell, 1992; Bell and Stuart, 1990) was confirmed as was the degree of resistance of NY 10355 and NY 10359 (Bell and van der Zwet, 1998). The high amount of feeding antixenosis of NJ B9 R1 T117 indicates that this selection may also be a promising source of resistance for breeding new cultivars with resistance to pear psylla. The apparent low susceptibility of US65064-044 was not expected based on the pedigree. None of the ancestors are known to be resistant. The observed reductions in live nymphs and nymphal feeding antixenosis need to be confirmed. Further studies of oviposition and development will be valuable to further characterize the degree of resistance in these selections.

\section{Literature Cited}

Bell, R.L. 1991. Ovipositional antixenosis-based host resistance to the pear psylla in Pyrus germplasm of east European origin. HortScience 26:710 (abstr.).

Bell, R.L. 1992. Additional east European Pyrus germplasm with resistance to pear psylla nymphal feeding. HortScience 27:412-413.

Bell, R.L. 2003. Resistance to pear psylla nymphal feeding of germplasm from central Europe. Acta Hort. 622:343-345.

Bell, R.L. and G.L. Puterka. 2004. Modes of host resistance in Pyrus to the pear psylla: A review. Acta Hort. 663:183-188.

Bell, R.L. and L.C. Stuart. 1990. Resistance in eastern European Pyrus germplasm to pear psylla nymphal feeding. HortScience 25:789-791.

Bell, R.L. and T. van der Zwet. 1998. Breeding for host resistance to pear psylla: Evaluation of parental germplasm. Acta Hort. 484:471-475.

Butt, B.A., L.C. Stuart, and R.L. Bell. 1988. Feeding behavior of pear psylla (Homoptera: Psyllidae) nymphs on susceptible and resistant Pyrus germplasm. J. Econ. Entomol. 81:1394-1397.

Butt, B.A., L.C. Stuart, and R.L. Bell. 1989. Feeding, longevity, and development of pear psylla (Homoptera:Psyllidae) nymphs on resistant and susceptible pear genotypes. J. Econ. Entomol. 82:458-461.

Harris, M.K. 1973. Host resistance to the pear psylla in a $P$. communis $\times P$. ussuriensis hybrid. Environ. Entomol. 2:883-887.
Harris, M.K. and R.C. Lamb. 1973. Resistance to the pear psylla in pears with Pyrus ussuriensis lineage. J. Amer. Soc. Hort. Sci. 98:378381.

Kogan, M. and E.E. Ortman. 1978. Antixenosis-A new term proposed to replace Painter's 'nonpreference' modality of resistance. Bull. Entomol. Soc. Am. 24:175-176.

Littell, R.C., G.A. Milliken, W.W. Stroup, and R.D. Wolfinger. 1996. SAS ${ }^{\circledR}$ system for mixed models. SAS Institute, Inc., Cary, NC.

Painter, R.H. 1951. Insect resistance in crop plants. Macmillan, New York, NY.

Pasqualini, E., S. Civolani, S. Musacchi, V. Ancarani, L. Dondini, P. Robert, and P. Baronio. 2006. Cacopsylla pyri behaviour on new pear selections for host resistance programs. Bull. Insectology 59:27-37.

Puterka, G.L. 1997. Intraspecific variation in pear psylla (Homoptera: Psyllidae) nymphal survival and development on resistant and susceptible pear. Environ. Entomol. 26:552558.

Quamme, H.A. 1984. Observations of psylla resistance among several pear cultivars and species. Fruit Var. J. 38:34-36.

Quarta, R. and D. Puggioni. 1985. Survey on the variety susceptibility to pear psylla. Acta Hort. 159:77-86.

Robert, P., J. Chausset, and M. Le Lézec. 1999. Larval development of Cacopsylla pyri (L.) [Homoptera: Psyllidae] on two resistant Pyrus genotypes. IOBC WPRS Bull. 22:89-91.

Robert, P., P. Guérif, J. Lemoine, and M. Le Lézec. 2004. Criblage de genotypes de Pyrus vis-à-vis de la résistance au psylla du poirier Cacopsylla pyri (L.). Cahiers Agricultures 13:349-354.

Robert, P., T. Raimbault, M. Le Lézec, and M.H. Simard. 2005. Resistance of some Pyrus communis cultivars and Pyrus hybrids to the pear psylla Cacopsylla pyri (Homoptera, Psyllidae). Acta Hort. 671:571-575.

SAS Institute Inc. 1990. SAS ${ }^{\circledR}$ procedures guide, Version 6, Third edition. SAS Institute Inc., Cary, NC.

Saxton, A.M. 1998. A macro for converting mean separation output to letter groupings in Proc Mixed. Proc. 23rd SAS Users Group Intl., SAS Institute Inc., Cary, NC. p. 1243-1246.

Steel, R.G.D. and J.H. Torrie. 1960. Principles and procedures of statistics-With special references to the biological sciences. McGraw-Hill, New York, NY.

USDA, ARS, National Genetic Resources Program. 2012. Germplasm Resources Information Network (GRIN) [online database]. National Germplasm Resources Laboratory, Beltsville, MD. 18 Dec. 2012. <http://www.ars. usda.gov/SP2UserFiles/Place/53581500/catalogs/ pyrpolyploid.html>.

van der Zwet, T., V. Cociu, J. Czarecki, J. Nyeki, and J. Blazek. 1989. Collecting Pyrus germplasm in Romania, Poland, Hungary, and Czechoslovakia. HortScience 24:420-424.

van der Zwet, T., D. Stankovic, and B. Ristevski. 1987. Collecting Pyrus germplasm in Yugoslavia. HortScience 22:15-21.

Westigard, P.H., M.N. Westwood, and P.B. Lombard. 1970. Host preference and resistance of Pyrus species to the pear psylla, Psylla pyricola Föerster. J. Amer. Soc. Hort. Sci. 95:34-36. 